\title{
イネ穂枯れの病原菌の種類と発病環境 および防除時期について
}

\author{
中西 勇*・都築 仁*・田辺 潔* 小出仁士** \\ The Causal Fungi of Rice Ear Blighting, Factors Affecting \\ its Incidence, and Proper Timing of its Chemical Control
}

\section{Isamu Nakanishi, Hitoshi Tsuzuki, Kiyoshi Tanabe and Hitoshi Koide}

\begin{abstract}
摘要 : 穂枮れの発生原因となる病原菌の種類を調査し, ごま葉枯病の葉身発病と穂枯れとの関係を究明すると ともに穂枯れ防除の薬剤散布適期をつかむために試験 を行なった。
\end{abstract}

1）県内各地の穗枯れから寄生菌の種類を調查する とHelminthosporium 拉よび Cladosporium 菌が普遍的 に検出され, Pyricularia および Cercospora菌は地域性, 年次により変動が大きかった。よって愛知県における 穂枯れの多くはごま葉枮病菌の寄生によるものとみな
される。

2）ごま葉枯病の葉身発病と穂枯れの発生との関係 については，自然罪場でははっきりした傾向がつかめ なかったが，還元状態などで氷稲根部の活力を低下さ せるとごま葉枯病の発生が葉身および穂で助長される ことを認めた。

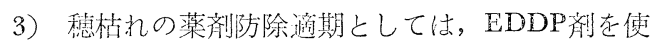
用した場合，穗揃期以降傾穂期の散布が有効であった。

\section{1. 緒言}

西南暖地水稲においては収穫間ぎわに熟色が悪くな る症状がしばしばみられ，変色穂首・穂焼け・穂枯れ 症状などといわれていたが，これらの現象を「穂枯れ 」と称することになり ${ }^{3)}$ ，穂枮れを抗こす病原菌の種 類についていろいろ究明されつつある。愛知県におい ても同様な症状がみられるので, 寄生菌の種類苍調查 し，穗枯れの原因となっている病原菌を明らかにする とともに，その多くがごま葉枯病菌と考えられるため 葉身のごま葉枯病の発生と穂枯れとの関係を追究し, 同時に薬剤防除における適期を把握しようとして試験 を行なった。

な打穂枯れの病原菌の種類調査市よびイネ葉身の発 病と穂の発病との関係については, 東海・近紋地区各 府県との連絡試験として実施した。

本矿究を実施するに当り，種々有益な助吾杂いただ いた東海近畿農業試験場病害研究琧長江塚昭與氏，元 愛知県農慈試験場長岩瀬茂基氏ならびに試料を採取し, 送付していただいた県内各農業改良普及所, 病害虫防
除所の方々に深く感謝の意を表したい.

\section{2. 㯖袩れの䦄から検出される菌類の種類}

1) 試験方法

県内各地から送付をうけた被害穂を穂首, 枝梗, 粐 などに区別し，穗首，枝枰は長さ $1 \mathrm{~cm}$ 内外に被害部 を切断，粐にあってはそのままをそれぞれ1地点10〜 20個体について調査した。被害部位の表面処理法とし ては殺菌水にて 5 回洗浄し, 1 回の洗㴔には30回以上 の振とうをくりかえして行なった，洗浄後はシャーレ 一中にて飽和湿度を保 $5,25^{\circ} \mathrm{C}$ の定温器に入れ，48 時問後調查個体の变色部に生じた菌㩘および胞子を直 接鏡検し寄生菌を分類した。 な掞 1 個体上に $2 \sim 3$ 種 類の菌を確認する場合がかなりるられるので, 被害部 分に占める胞子形成の範团により程度別に分けた。 1967，1968年は主として平坦部の試料が多く，1969， 1970年はほぼ県下全域の試料がえられた。

2) 試賖結果

1967年驻罧下35市町村の54地点について, 穂の霍病 部分 $5 \mathrm{~cm}$ 間に等生する菌の種類を， $2 / 3$ 以上の範国

* 愛知県農業総合試験埸作物研究所 $* *$ 現愛知県農業総合試験場 山間技術実験農場 
に胞子を生じているものを多, $2 / 3 \sim 1 / 3$ の範图のもの を中，1/3 以下の範囲のものを少として判定した．そ の結果は第 1 表のとおりであり, Helminthosporium お よび Gladosporium 菌はほとんどの被害穗から検出さ れた．次いで Alternaria 菌が全穗の $2 / 3$ から検出され たが， 1 穂当りの胞子発生程度はCladosporium 菌に比 較し少なかった．また Nigrospora菌と Fusarium 菌も わずかながら検出された．なおこの年は Pyricularia菌 は 1 点検出されたにすぎなかった。

第 1 表 穂枯れの穂から検出された菌の種類

\begin{tabular}{lrrrr}
\hline \multirow{2}{*}{\multicolumn{1}{c}{ 菌の種類 }} & \multicolumn{4}{c}{ 検出程度別地点数 } \\
\cline { 2 - 5 } & 多 & 中 & 少 & 無 \\
\hline Pyricularia & 0 & 1 & 0 & 53 \\
Helminthosporium & 9 & 14 & 27 & 4 \\
Cladosporium & 23 & 19 & 12 & 0 \\
Fusarium & 0 & 0 & 4 & 54 \\
Alternaria & 0 & 0 & 32 & 22 \\
Nigrospora & 0 & 0 & 6 & 48 \\
そ の & 0 & 0 & 9 & 45 \\
\hline
\end{tabular}

1968年には県下29市町村の58地点について，前年と 同じ方法にて調查した結果は第 2 表のごとくであり, Cladosporium 菌の検出が最も多く, Helminthosporium 菌 がこれに次いて多くみられた。 Nigrospora, Cercospora 菌もみられたが，この年にはCercospora菌の検出率が 比較的高かった. なお Pyricularia菌がかなり多く検出 され, 穂いもちの後期発生がやや多かったことを示し ていた。

1969年には23市町村の44地点の被害穂について穂首,

第 2 表 穂枯れの穗から検出された菌の種類

(1968)

\begin{tabular}{lcccc}
\hline \hline \multirow{2}{*}{ 菌の種類 } & \multicolumn{4}{c}{ 検出程度別地点数 } \\
\cline { 2 - 5 } & 多 & 中 & 少 & 無 \\
\hline Pyricularia & 1 & 6 & 6 & 45 \\
Helminthosporium & 8 & 3 & 28 & 19 \\
Cercospora & 0 & 0 & 25 & 33 \\
Alternaria & 0 & 0 & 16 & 42 \\
Cladosporium & 5 & 6 & 37 & 10 \\
Nigrospora & 0 & 0 & 29 & 39 \\
そ の $\quad$ 他 & 0 & 0 & 16 & 42 \\
\hline
\end{tabular}

枝梗，粐の各部位の寄生菌を調査した結果は第 $3 \sim 4$ 表のごとくで,Cladosporium 菌とHelminthosporium 菌 の検出率が高く, Pyricularia 菌も検出が多く注目され た。また穂の部位別にみるとHelminthosporium 菌は枝 梗と粐で多くみられ, 穂首では少なく, Cercospora 菌 は穂首，枝梗で多くみられ，粐では検出率が低かった。 地域的には Helminthosporium, Cladosporium 菌は県下 全域から検出されたが Cercospora 菌は地域的に限定さ れていた。

第 3 表 穂枯れの穗の部位から検出された菌 の種類 (1969)

\begin{tabular}{|c|c|c|c|c|c|c|}
\hline \multirow{2}{*}{ 菌の種類 } & \multirow{2}{*}{ 部位 } & \multicolumn{4}{|c|}{ 検出程度別地点数 } & \multirow{2}{*}{ 検出率 } \\
\hline & & 多 & 中 & 少 & 無 & \\
\hline \multirow{3}{*}{ Pyricularia } & 首 & 2 & 4 & 9 & 29 & $11.6 \%$ \\
\hline & 枝梗 & 1 & 9 & 7 & 27 & 14.8 \\
\hline & 粐 & 0 & 0 & 6 & 36 & 1.4 \\
\hline \multirow{3}{*}{ Helminthosporium } & 首 & 0 & 2 & 7 & 35 & 3.6 \\
\hline & 枝梗 & 4 & 11 & 18 & 11 & 27.3 \\
\hline & 粐 & 0 & 12 & 14 & 16 & 16.4 \\
\hline \multirow{3}{*}{ Cercospora } & 首 & 1 & 6 & 3 & 34 & 7.0 \\
\hline & 枝梗 & 1 & 4 & 6 & 33 & 9.5 \\
\hline & 粐 & 0 & 0 & 5 & 37 & 1.6 \\
\hline \multirow{3}{*}{ Alternaria } & 首 & 0 & 5 & 13 & 26 & 8.0 \\
\hline & 枝梗 & 0 & 4 & 17 & 23 & 10.0 \\
\hline & 粐 & 0 & 3 & 14 & 25 & 7.1 \\
\hline \multirow{3}{*}{ Fusarium } & 首 & 1 & 15 & 14 & 14 & 20.7 \\
\hline & 枝梗 & 0 & 5 & 18 & 26 & 8.4 \\
\hline & 粐 & 0 & 4 & 11 & 27 & 5.7 \\
\hline \multirow{3}{*}{ Cladosporium } & 首 & 6 & 25 & 5 & 8 & 41.8 \\
\hline & 枝梗 & 1 & 19 & 7 & 17 & 22.5 \\
\hline & 粐 & 0 & 8 & 17 & 17 & 13.3 \\
\hline \multirow{3}{*}{ Nigrospora } & 首 & 0 & 1 & 6 & 37 & 3.0 \\
\hline & 枝梗 & 0 & 0 & 4 & 40 & 1.1 \\
\hline & 粐 & 0 & 0 & 7 & 35 & 2.1 \\
\hline \multirow{3}{*}{ そ の 他 } & 首 & 0 & 1 & 6 & 37 & 3.6 \\
\hline & 枝梗 & 0 & 2 & 11 & 31 & 6.1 \\
\hline & 粐 & 1 & 11 & 13 & 17 & 28.6 \\
\hline
\end{tabular}

1970年は33方町村の38地点について被害穂の部位別 に寄生菌を調查した．その結果は第 5 ～ 6 表のごとく で, 穂首では Cladosporium 菌が甚しく多く検出され, Nigrospora菌もかなり検出されたが, Helminthosporium, Pyricularia 菌は検出率がやや低かった。一方枝梗では 
第 4 表 穂枯れ寄生菌の地域別検出程度（1969）

\begin{tabular}{|c|c|c|c|c|c|c|c|}
\hline \multirow{2}{*}{ 菌の種類 } & \multicolumn{3}{|c|}{ 平 } & \multicolumn{2}{|l|}{ 坦 } & \multirow{2}{*}{$\begin{array}{l}\text { 中山 } \\
\text { 間 } \\
\text { (新 } \\
\text { 城) }\end{array}$} & \multirow{2}{*}{$\begin{array}{l}\text { 山間 } \\
\text { （西 } \\
\text { 三河 } \\
\end{array}$} \\
\hline & 尾張 & $\begin{array}{l}\text { 海部 } \\
\text { 郡 }\end{array}$ & $\begin{array}{l}\text { 知多 } \\
\text { 郡 }\end{array}$ & $\begin{array}{l}\text { 西三 } \\
\text { 河 }\end{array}$ & $\begin{array}{l}\text { 東三 } \\
\text { 河 }\end{array}$ & & \\
\hline Pyricularia & 0 & - & 0 & 0 & (2) & (a) & 0 \\
\hline $\begin{array}{l}\text { Helmintho- } \\
\text { sporium }\end{array}$ & () & (2) & $\bigcirc$ & 0 & $\bigcirc$ & (a) & 0 \\
\hline Cercospora & 0 & 0 & - & - & - & $\bigcirc$ & 0 \\
\hline Alternaria & $\bigcirc$ & 一 & $\bigcirc$ & 0 & $\bigcirc$ & $\bigcirc$ & $\bigcirc$ \\
\hline Fusarium & $\bigcirc$ & 0 & $\bigcirc$ & 0 & $\bigcirc$ & $\bigcirc$ & $\bigcirc$ \\
\hline Cladosporium & (a) & $\bigcirc$ & (a) & (a) & $\bigcirc$ & $\bigcirc$ & (a) \\
\hline Nigrospora & $\bigcirc$ & 一 & $\bigcirc$ & 0 & - & - & 0 \\
\hline そ の 他 & $\bigcirc$ & - & $\bigcirc$ & (a) & $\bigcirc$ & (a) & 0 \\
\hline
\end{tabular}

Cladosporium, Helminthosporium 菌の検出が多く, 次い で Pyricularia 菌の検出がみられた。なお地域別では Helminthosporium 菌は全域で検出されたが, Pyricularia 菌は地域的に多少の差がみられ，中山間〜山間部およ び平坦部の一部に散発傾向であった。また Cercospora 菌は地域性が顕著で西三河山間部，尾張部の一部でみ られた。
第 5 表 穂枯れの穂の部位から検出された菌 の種類 (1970)

\begin{tabular}{|c|c|c|c|c|c|c|}
\hline \multirow{2}{*}{ 菌の種類 } & \multirow{2}{*}{ 部位 } & \multicolumn{4}{|c|}{ 検出程度別地点数 } & \multirow{2}{*}{ 検出率 } \\
\hline & & 多 & 中 & 少 & 無 & \\
\hline Pyricularia & $\begin{array}{c}\text { 首 } \\
\text { 枝梗 }\end{array}$ & $\begin{array}{l}2 \\
2\end{array}$ & $\begin{array}{l}1 \\
1\end{array}$ & $\begin{array}{r}9 \\
13\end{array}$ & $\begin{array}{l}26 \\
22\end{array}$ & $\begin{array}{c}9.5 \% \\
10.0\end{array}$ \\
\hline Helminthosporium & $\begin{array}{c}\text { 首 } \\
\text { 枝梗 }\end{array}$ & $\begin{array}{l}1 \\
4\end{array}$ & $\begin{array}{l}2 \\
9\end{array}$ & $\begin{array}{r}8 \\
21\end{array}$ & $\begin{array}{r}27 \\
4\end{array}$ & $\begin{array}{r}8.1 \\
30.5\end{array}$ \\
\hline Cercospora & $\begin{array}{c}\text { 首 } \\
\text { 枝梗 }\end{array}$ & $\begin{array}{l}0 \\
0\end{array}$ & $\begin{array}{l}1 \\
0\end{array}$ & $\begin{array}{l}3 \\
8\end{array}$ & $\begin{array}{l}34 \\
30\end{array}$ & $\begin{array}{l}2.0 \\
1.9\end{array}$ \\
\hline Alternaria & $\begin{array}{c}\text { 首 } \\
\text { 枝梗 }\end{array}$ & $\begin{array}{l}0 \\
0\end{array}$ & $\begin{array}{l}2 \\
3\end{array}$ & $\begin{array}{l}18 \\
24\end{array}$ & $\begin{array}{l}18 \\
11\end{array}$ & $\begin{array}{l}8.1 \\
7.6\end{array}$ \\
\hline Fusarium & $\begin{array}{c}\text { 首 } \\
\text { 枝梗 }\end{array}$ & $\begin{array}{l}0 \\
0\end{array}$ & $\begin{array}{l}1 \\
1\end{array}$ & $\begin{array}{r}5 \\
13\end{array}$ & $\begin{array}{l}32 \\
24\end{array}$ & $\begin{array}{l}2.2 \\
5.1\end{array}$ \\
\hline Cladosporium & $\begin{array}{c}\text { 首 } \\
\text { 枝梗 }\end{array}$ & $\begin{array}{r}20 \\
3\end{array}$ & $\begin{array}{l}13 \\
16\end{array}$ & $\begin{array}{r}5 \\
18\end{array}$ & $\begin{array}{l}0 \\
1\end{array}$ & $\begin{array}{l}72.2 \\
34.5\end{array}$ \\
\hline Nigrospora & $\begin{array}{c}\text { 首 } \\
\text { 枝梗 }\end{array}$ & $\begin{array}{l}1 \\
0\end{array}$ & $\begin{array}{l}2 \\
2\end{array}$ & $\begin{array}{l}12 \\
13\end{array}$ & $\begin{array}{l}23 \\
23 \\
\end{array}$ & $\begin{array}{r}16.7 \\
6.8\end{array}$ \\
\hline Curvularia & 首 & $\begin{array}{l}0 \\
0\end{array}$ & $\begin{array}{l}0 \\
0\end{array}$ & $\begin{array}{l}7 \\
9\end{array}$ & $\begin{array}{l}31 \\
29\end{array}$ & $\begin{array}{l}1.2 \\
1.7\end{array}$ \\
\hline Phoma & $\begin{array}{c}\text { 首 } \\
\text { 枝梗 }\end{array}$ & $\begin{array}{l}0 \\
0 \\
\end{array}$ & $\begin{array}{l}1 \\
1\end{array}$ & $\begin{array}{r}5 \\
13\end{array}$ & $\begin{array}{l}32 \\
24\end{array}$ & $\begin{array}{l}2.2 \\
5.1 \\
\end{array}$ \\
\hline そ の 他 & $\begin{array}{c}\text { 首 } \\
\text { 枝梗 }\end{array}$ & $\begin{array}{l}0 \\
0\end{array}$ & $\begin{array}{l}0 \\
0\end{array}$ & $\begin{array}{r}8 \\
\text { I5 }\end{array}$ & $\begin{array}{l}30 \\
23\end{array}$ & $\begin{array}{l}2.0 \\
3.2\end{array}$ \\
\hline
\end{tabular}

第 6 表 穂枯れ寄生菌の地域別検出率 (1970)

\begin{tabular}{|c|c|c|c|c|c|c|c|c|}
\hline \multirow{2}{*}{ 菌の種類 } & \multirow{2}{*}{ 部位 } & \multicolumn{3}{|c|}{ 平 } & \multicolumn{2}{|l|}{ 坦 } & \multirow{2}{*}{$\begin{array}{l}\text { 中山間 } \\
\text { (西三河) }\end{array}$} & \multirow{2}{*}{$\begin{array}{l}\text { 山間 } \\
\text { (東三河) }\end{array}$} \\
\hline & & 尾 張 & 海部郡 & 知多郡 & 西三河 & 東三河 & & \\
\hline Pyricularia & 枝 ${ }^{\text {首 }}$ & $\begin{array}{l}12 \% \\
12\end{array}$ & $\begin{array}{l}0 \% \\
0\end{array}$ & $\begin{array}{l}6 \% \\
3\end{array}$ & $\begin{array}{l}2 \% \\
2\end{array}$ & $\begin{array}{c}13 \% \\
9\end{array}$ & $\begin{array}{l}22 \% \\
26\end{array}$ & $\begin{array}{l}4 \% \\
15\end{array}$ \\
\hline Helminthosporium & 枝 $^{\text {首 }}$ & $\begin{array}{r}9 \\
28\end{array}$ & $\begin{array}{l}0 \\
9\end{array}$ & $\begin{array}{r}1 \\
31\end{array}$ & $\begin{array}{r}6 \\
11\end{array}$ & $\begin{array}{r}3 \\
34\end{array}$ & $\begin{array}{l}13 \\
43\end{array}$ & $\begin{array}{l}24 \\
57\end{array}$ \\
\hline Cercospora & 枝 $^{\text {首 }}$ & $\begin{array}{l}2 \\
4\end{array}$ & $\begin{array}{l}0 \\
0\end{array}$ & $\begin{array}{l}0 \\
0\end{array}$ & $\begin{array}{l}0 \\
0\end{array}$ & $\begin{array}{l}0 \\
6\end{array}$ & $\begin{array}{r}10 \\
1\end{array}$ & $\begin{array}{l}0 \\
0\end{array}$ \\
\hline Alternaria & 枝 $^{\text {首 }}$ & $\begin{array}{r}12 \\
9\end{array}$ & $\begin{array}{r}7 \\
16\end{array}$ & $\begin{array}{r}13 \\
6\end{array}$ & $\begin{array}{l}5 \\
5\end{array}$ & $\begin{array}{l}5 \\
9\end{array}$ & $\begin{array}{l}5 \\
4\end{array}$ & $\begin{array}{l}4 \\
4\end{array}$ \\
\hline Fusarium & 枝 $^{\text {首 }}$ & $\begin{array}{l}6 \\
3\end{array}$ & $\begin{array}{l}1 \\
2\end{array}$ & $\begin{array}{l}0 \\
0\end{array}$ & $\begin{array}{l}23 \\
13\end{array}$ & $\begin{array}{r}16 \\
5\end{array}$ & $\begin{array}{l}0 \\
0\end{array}$ & $\begin{array}{l}4 \\
2\end{array}$ \\
\hline Cladosporium & 枝 ${ }^{\text {首 }}$ & $\begin{array}{l}64 \\
25\end{array}$ & $\begin{array}{l}81 \\
31\end{array}$ & $\begin{array}{l}82 \\
35\end{array}$ & $\begin{array}{l}69 \\
35\end{array}$ & $\begin{array}{l}87 \\
54\end{array}$ & $\begin{array}{l}79 \\
26\end{array}$ & $\begin{array}{l}45 \\
45\end{array}$ \\
\hline Nigrospora & 枝 $^{\text {首 }}$ & $\begin{array}{l}11 \\
15\end{array}$ & $\begin{array}{r}31 \\
0\end{array}$ & $\begin{array}{l}2 \\
3\end{array}$ & $\begin{array}{r}15 \\
4\end{array}$ & $\begin{array}{l}8 \\
5\end{array}$ & $\begin{array}{l}16 \\
11\end{array}$ & $\begin{array}{l}3 \\
0\end{array}$ \\
\hline Curuvularia & 枝 $^{\text {首 }}$ & $\begin{array}{l}2 \\
1\end{array}$ & $\begin{array}{l}1 \\
6\end{array}$ & $\begin{array}{l}0 \\
0\end{array}$ & $\begin{array}{l}0 \\
1\end{array}$ & $\begin{array}{l}0 \\
0\end{array}$ & $\begin{array}{l}3 \\
5 \\
\end{array}$ & $\begin{array}{l}1 \\
1\end{array}$ \\
\hline Phoma & 枝 首 & $\begin{array}{l}2 \\
6\end{array}$ & $\begin{array}{l}16 \\
14\end{array}$ & $\begin{array}{l}0 \\
0 \\
\end{array}$ & $\begin{array}{l}0 \\
7 \\
\end{array}$ & $\begin{array}{l}0 \\
2 \\
\end{array}$ & $\begin{array}{l}0 \\
4 \\
\end{array}$ & $\begin{array}{l}1 \\
1\end{array}$ \\
\hline その他 & 枝 ${ }^{\text {首 }}$ & $\begin{array}{l}5 \\
6\end{array}$ & $\begin{array}{l}0 \\
0\end{array}$ & $\begin{array}{l}4 \\
0\end{array}$ & $\begin{array}{l}0 \\
3\end{array}$ & $\begin{array}{l}0 \\
1\end{array}$ & $\begin{array}{l}0 \\
1\end{array}$ & $\begin{array}{l}3 \\
2\end{array}$ \\
\hline
\end{tabular}




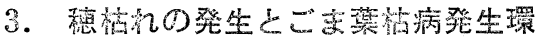 境亡の関係}

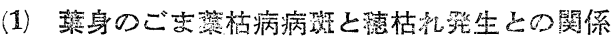

穂枯れの主な原因としてごま葉枯病菌が考えられる ので，イネ葉身のごま葉枯病と穂枯れの発生に関連が あるか否かについて調査走行なった。

1) 試験方法

穂枯れの多〜中程度の発生地苍選び，1969年は２力 所，1970年は 4 市町村 5 力所の罡場において, 出㮴期 〜糊熟期の時期に調查した。葉身のごま葉枮病病斑に ついては各阔場から任意に10株を選び，各秼から3 荃 計 30 茎について上位 3 葉の葉身中央 $5 \mathrm{~cm}$ 間の病班数 を調査した。一方穂枯れについては同一四場で任意に 10株を選び，1969年は病枝梗率，病粐率を1株から 1 茎抽出して調へ，病穂首率は40株全穂について調査し， 1970年は病穂首率, 病枝梗率を調查した。

\section{2) 試験結果}

1969年は激発地の豊田市と中程度の発生地の安城市 の婳場で調べたが，第 7 表のごとく葉身の病斑数と䅼 枯れの被害程度とは必ずしも相関が認められなかった。 1970年の結果は第 8 表のごとくで, 葉身のごま葉枯病 病斑数は鼠場によりかなり差がみられ，またここま葉
枮病とすじ薬枯满が混発し, 後者が優占する粗場もみ られ，ごま葉枯病病班数との関係を判断するのに困難 な面もあるが，概して葉身の病斑数の多い国場は，穂 首・枝梗の穂枯れも多くなる傾向がみられた。

\section{(2) 㯖祜れとイ卡根部の活力との関係}

イネが根腐れをおこしやすい状態になった場合，秋 落ち現象となりごま葉枮病が多発することが知られて いるので, 人為的に環境をかえてごま葉枯病の発生し やすい条件を与え，穂枯れの発生にどのように影響す るかを検討した。

1) 試験方法

1969年に水田土萑を入れたコンクリート槽 $(100 \times$ $100 \times 30 \mathrm{~cm})$ に水稲を植え，生育期間中の水管理を湛 水と間断かん水 (5 日笵水， 2 日落水) にわけ, さら に湛水では幼穂形成期以後と出穂期以後にそれぞれ硫 化水素処理（硫化ソーダ $100 \mathrm{~g} / \mathrm{m}^{2} 10$ 日ごと施用）を 行なった区を設け，間断かん水では常時間断かん水区 と幼穗形成期以後間哳かん水を行なった区を設け，穗 枯れの発生率および止葉のごま葉枯病病班数を調べた。 な就これら処理による水稻根の影響をみるために各区 に 1 箱ずつルートボックス $(20 \times 20 \times 12 \mathrm{~cm})$ を入れ， 水稲根の活力の程度を黑色根の比率で判定した。

第 7 表 葉身のごま葉枯病の発生と穂枯れとの閭係 (1969)

\begin{tabular}{|c|c|c|c|c|c|c|c|c|}
\hline \multirow{2}{*}{ 場所·品種 } & \multirow{2}{*}{ 調坥時期 } & \multicolumn{4}{|c|}{ ごま葉枯病病斑数 ( $5 \mathrm{~cm}$ 間) } & \multicolumn{3}{|c|}{ 穂 枯 れ 率 } \\
\hline & & 止 葉 & 次菜 & 第 3 葉 & 計 & 首 & 枝 梗 & 粐 \\
\hline \multirow{2}{*}{ 豊回宁（秋 啨） } & 傾穂初期 & 6.3 & 4.6 & 13.8 & 24.7 & \multirow{2}{*}{$0.7 \%$} & \multirow{2}{*}{$26.3 \%$} & \multirow{2}{*}{$25.4 \%$} \\
\hline & 成熹期 & 9.5 & 8.1 & 9.8 & 27.4 & & & \\
\hline \multirow{2}{*}{ 安城市（愛知旭） } & 偵㯖初期 & 0.1 & 0.5 & 1.6 & 2.2 & \multirow{2}{*}{16.1} & \multirow{2}{*}{37.8} & \multirow{2}{*}{27.6} \\
\hline & 成熟期 & 2.9 & 4.7 & 4.8 & 12.4 & & & \\
\hline
\end{tabular}

第 8 表 菱身のごま菜枯病の発生と䅼枮れとの関係 (1970)

\begin{tabular}{|c|c|c|c|c|c|c|c|}
\hline & \multirow{2}{*}{ 場所·品䅡 } & \multicolumn{4}{|c|}{ 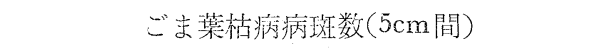 } & \multicolumn{2}{|c|}{ 穂 枯 れ 率 } \\
\hline & & 止菻 & 次 葉 & 第 3 葉 & 訪 & 首 & 枝 梗 \\
\hline 安 & 城 柿 (愛知 2 号) & 0 & 0 & 0 & 0 & $24.5 \%$ & $27.0 \%$ \\
\hline 安 & 城市 (秋啨) & 1.0 & 1.5 & 2.8 & 5.3 & 5.4 & 21.4 \\
\hline & 尧郡藤网村（初 穂 波） & 20.5 & 15.3 & 15.9 & 51.7 & 68.5 & 31.5 \\
\hline & 郡一宮町（新山吹） & 8.0 & 6.0 & 7.6 & 21.6 & 3.3 & 46.7 \\
\hline & 茂郡小原村（秋 & $\begin{array}{c}0.5 \\
(14.6)\end{array}$ & $\begin{array}{c}0.3 \\
(20.2)\end{array}$ & $\begin{array}{c}0.3 \\
(22.6)\end{array}$ & $\begin{array}{c}1.1 \\
(57.4)\end{array}$ & 87.7 & 11.7 \\
\hline
\end{tabular}

注）（）内はすじ葉枯病病斑数 


\section{2) 試験結果}

6 月に植えた水稲について，成熟期の穗枯れ被害度 と止葉のごま葉枯病病斑数扰よびルートボックス中に 扎ける傾穗初期と成熟期の黑色根の比率を調べた結果 は第 1 図のごとくであり，湛水区の場合は還元状態が 生育後期に甚しくなり, 黑色根の比率がきわめて高く, 硫化水素処理によりさらに助長された。間断かん水 区は還元状態が軽微で黑色根の比率がきわめて低かっ た、槙枮れの被書度は湛水区は間断か九水区よりも明 らかに多く, 硫化水素処理により一層被害が多くなっ ていた。また止葉のごま葉枯病病班数も湛水区では明

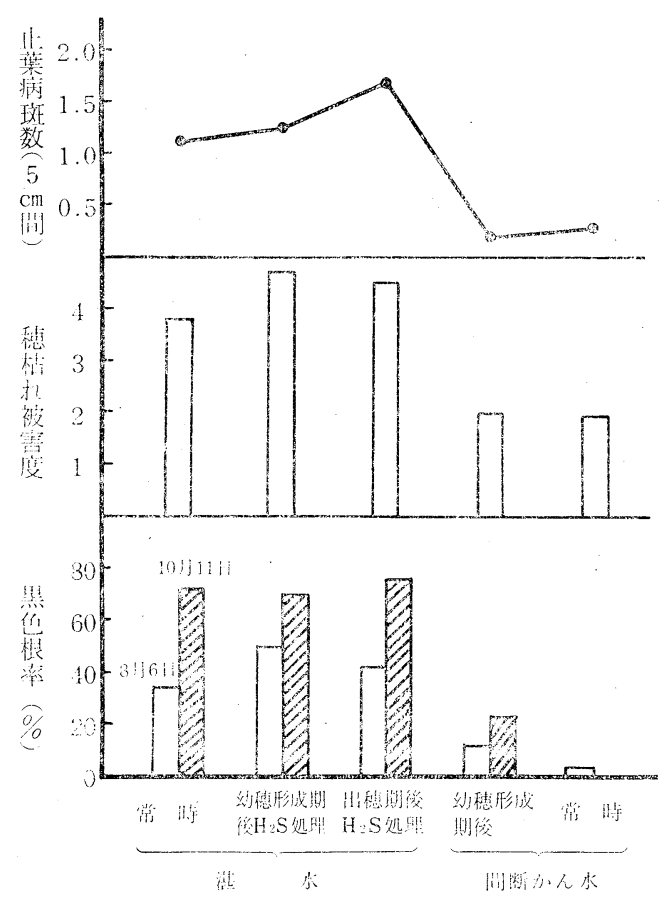

第 1 図 水稲根部の活力と穂枮れ発生との閶係
らかに多くなった，なおこの試験では止薬の病斑数と 穂枯れとの間にかなりの相関関係があるようにみられ た。

\section{4. 穂棺れ防除のための薬剤散布適期}

イネごま葉枯病に起因する穂枯れに対し有效な薬郕 を選び出すため，1967～1969年の3力年間穌枮れの発 生地に执いて試験を実施した結果，トリアジン剂， TPTH用, マンネブの混合剤, 有禨際系のEDDP 剂

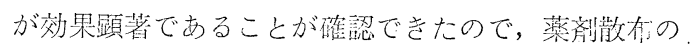
適期を把握するために試験苍行なった。

1) 試験方法

1968年は品種・日本晴（出穂期 8 月20日）を使用し， 穂ばらみ〜㑯䅹初期の間に EDDP 乳剂（エチルジフ ェニールジチオホスフ $=$ ート $30 \%$ ） 1000 倍液 $150 \ell / 10 \mathrm{a}$

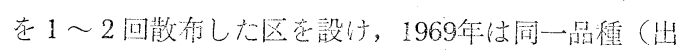

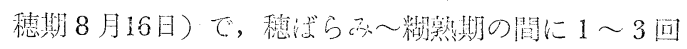

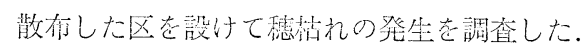

穂枯れの被害度は，A（穗首から罹病した穌数）, B (枝㴍 $2 / 3$ 以上惟病した穂数), $\mathrm{C}$ (同 $2 / 3 \sim 1 / 3$ ), $\mathrm{D}$ (同 $1 / 3$ 以下) に分け，次式により算出した.

$$
\text { 被害度 }=\frac{\mathrm{A}+0.7 \mathrm{~B}+0.5 \mathrm{C}+0.3 \mathrm{D}}{\text { 総 穂 数 }} \times 100
$$

2) 試験結㪙

1968年の結果は第 9 表のごとくであり, EDDP 乳 凧の效果仙すぐれており，穂揃〜傾㯖期の散布がまさ り䅹代らみ期では効果が劣った。とくに穂揄期と傾穂 初期の 2 回散布は效果蹎堷であった。な扮同時に止菜 におけるごま葉枯病病斑数を調べたところ瞴散布では かなりの病班数を認めたが、EDDP乳剤の散布された 区では涠散布の $1 / 2$ 程度となっていた。

1969年の結果仙第10表のごとく 1 回散布では傾稩初

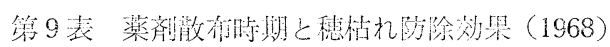

\begin{tabular}{|c|c|c|c|c|c|c|c|}
\hline \multirow{2}{*}{ 薬 䘞 名 } & 散 & 布 時 & I⿰氵) & \multirow{2}{*}{ 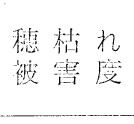 } & \multicolumn{2}{|c|}{ 取旦（玄米回） } & \multirow{2}{*}{$\begin{array}{c}\text { ごま葉枯病病珱数 } \\
\text { (止葉 } 5 \mathrm{~cm} \text { 間) }\end{array}$} \\
\hline & $\begin{array}{ll}\text { 魏ばら } \\
2 \\
\text { み }\end{array}$ & 禤 揃 期 & 傾䅦初期 & & 10a当り & 数 & \\
\hline \multirow{5}{*}{ EDDP 乳剂 } & $\bigcirc$ & - & - & $6.5 \%$ & $518 \mathrm{~kg}$ & 100 & 5.3 \\
\hline & - & $\bigcirc$ & - & $4.0^{*}$ & 510 & 99 & 6.3 \\
\hline & - & - & 0 & $3.6^{*}$ & 508 & 98 & 6.6 \\
\hline & $\bigcirc$ & $\bigcirc$ & - & $3.5^{*}$ & 508 & 98 & 5.9 \\
\hline & - & 0 & 0 & $2.1^{*}$ & 521 & 101 & 5.2 \\
\hline TPTH 粉刘 & $\bigcirc$ & $\bigcirc$ & - & 5.4 & 525 & 102 & 6.7 \\
\hline 篤 散 布 & - & - & - & 10.1 & 517 & 100 & 10.3 \\
\hline
\end{tabular}


第10表 EDDP乳剂の散布時期と穂枯れ防除効果（1969）

\begin{tabular}{|c|c|c|c|c|c|c|c|c|c|c|}
\hline \multirow{2}{*}{ 区 別 } & \multicolumn{3}{|c|}{ 散 } & 布 & 時 & \multicolumn{2}{|l|}{ 期 } & \multirow{2}{*}{$\begin{array}{l}\text { 穂枯れ } \\
\text { 被害度 }\end{array}$} & \multicolumn{2}{|c|}{ 収量（玄米重） } \\
\hline & $\begin{array}{c}\text { 穂ばらみ } \\
(8.11)\end{array}$ & $\begin{array}{l}\text { 出 穗 } \\
(8.16)\end{array}$ & $\begin{array}{l}\text { 穗 揃 } \\
(8.19)\end{array}$ & $\begin{array}{l}\text { 穗 揃 } \\
(8.22)\end{array}$ & $\begin{array}{c}\text { 傾 穂 初 } \\
(8.26)\end{array}$ & $\begin{array}{l}\text { 乳 熟 } \\
(9.3)\end{array}$ & $\begin{array}{l}\text { 糊 熟 } \\
(9.8)\end{array}$ & & 10a当り & 指 \\
\hline \multirow{5}{*}{$\begin{array}{l}1 \\
\text { 回 } \\
\text { 散 } \\
\text { 布 }\end{array}$} & 0 & - & - & 一 & - & - & - & $9.8 \%$ & $454 \mathrm{~kg}$ & 96 \\
\hline & - & 一 & 0 & - & - & 一 & - & 8.9 & 482 & 102 \\
\hline & 一 & - & - & - & 0 & 一 & 一 & 2.8 & 474 & 101 \\
\hline & - & - & - & 一 & - & 0 & - & 3.3 & 462 & 98 \\
\hline & - & - & - & - & - & - & $\bigcirc$ & 10.4 & 446 & 95 \\
\hline \multirow{3}{*}{ 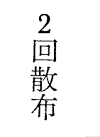 } & 0 & - & 0 & - & - & 一 & - & 3.0 & 497 & 106 \\
\hline & - & - & 0 & - & 0 & 一 & 一 & 3.9 & 485 & 103 \\
\hline & - & 0 & 一 & 0 & - & - & - & 2.7 & 505 & 107 \\
\hline 無散布 & - & 一 & - & - & 一 & - & 一 & 13.4 & 472 & 100 \\
\hline
\end{tabular}

期〜乳熟期の散布が穗枯れの被害少なく効果が顕著で あった. 2 回散布はいずれも效果が認められた.

\section{5. 考察}

穂枯れの病原菌については木谷ら5)が詳細に研究し て打り, ごま葉枯病菌 (H. oryzae) のほか雲形病菌 (Rhy. oryzae), Curvularia lunata, Aliernaria oryzae な ぞを分離し，これらはいずれも穂に対する病原性を認 めたが, 被害穂から多く検出されるCladosporium cladosporioides 㧍よび Nigrospora oryzae は病原性がほと んどないとしている。一方越水ら ${ }^{6)}$ は褐色葉枯病と雲 形病とは同一種の菌であるとし, 穂に対する病原性も

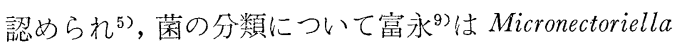
属で不完全時代は Fusarium nivale であるとした。 そ のほか鈴木ら ${ }^{8)}$ ( (小黑菌核病菌によっても穂への侵入 を認め穂枯れの原因になるとしている。またこれら穂 枯れに関与する病原菌の分離検出にあたって Pyricularia oryzae 含め $2 \sim 3$ 種類が混在していることも観 察されている.

筆者らの調査結果ではCladosporium 菌および Helminthosporium 菌洁いずれの年に批いも普遈的に 検出でき, Cercospora, Fusarium, Nigrospora および Pyricularia 菌は年により検出に差があった。またこれ らのうち病原性のある菌でも $2 \sim 3$ 種が混在している 場合がかなりみられた．穂の発病部位による菌の種類 については Helminthosporium 菌は穂首よりも枝梗に 多く検出された。また寄生菌の地域的分布については Helminthosporium 菌は県下全域から検出されたが, Pyricularia 菌はいもち病の発生しやすい中山問，山 間部での検出が比較的多く, Cercospora 菌については 地域性が顕著で, 検出地点では葉身のすじ葉枯病病斑
が目立った。な褐色葉枯病菌は被害穂から検出でき なからたが，山間部の一部で葉身に雲形病斑が甚しく みられる年もあり㯖枯れの原因になっている可能性は 十分考えられる。これら筆者らの調查結果について既 往の報告を参考に考察すると, 愛知県の多くで問題と なっている穂枯れを起こす病原菌としては，ごま葉 枯病菌が主体であると考えられ, 一部すじ葉枯病菌が あり，また祲色葉枯病菌も山間部では原因となってい るものと考えられる。調查試料から多く検出された Cladosporium, Nigrospora 菌などについてはイネ穂上 に存在する菌で穂枯れの第 1 次感染を起こす病原菌で はないと考えられる。

ごま葉枯病菌が穂に寄生する時期に関し, 藤井ら ${ }^{1,2}$ は出穗期以隆収穫期に近づくにしたがいごま葉枯病菌 の飛散が多くなり菜の病斑拉よび枝梗発病の增加と一 致し, 接種試検では乳熟期よりも糊熟期において枝梗 の発病が甚しいとしている。このことから葉身のごま 葉枯病病班数と穂枯れ発生との関係を調べた結果, 1969年は 2 力所で截培条件が異なっていたため両者の 関係注はっきりしなかったが，1970年は多少雨者の間 に関倸がみら杞るようであった。この点については自 然発病の一般苗場で調査したため, 品種・土壤・作期 などがかなり異なり雨者の関係を十分つかむことがで きなかったものと考えられる.ちなみに, 同一品種, 同一環境で土缺の還元状態を人為的に変化させた穂枯 れとイネ根部活力の試験の場合に, 葉身のごま葉枯病 病斑数と穂枯れ発生率にかなりの相関のあることが認 められた。

イネの生育環境 (土壤・水管理等)によってはごま 葉枯病の多発をまねき秋落ち現象をおこすことが知ら れているので，実験的にイネを秋落ち状態にさせて， 
穂枯れの発生を調査したところ, 常時湛水では土壤の 還元が生育後半に甚しくなり, 間断かん水に比べ穂枯 れの発生も増加し, とくに湛水状態で硫化水素の発生 を助長させると甚しくなった. 葉身のごま葉枯病の発 生と灌排水の関係については, 安ら ${ }^{11)} は$ 常時湛水は本 田初期の生育を助長し, 後期に秋落ち状態となりごま 葉枯病の発生を多くするとして扒り, 筆者らの試験で も同じ傾向を認め, 常時湛水で土壤還元が強くなると 水稲根の活力が低下し, 葉身および穂でのごま葉枯病 菌寄生を助長しているようであった。

穂枯れの防除薬蝺についてはごま葉枯病に起因す る穂枯れを対象として多くの試験がなされており, ト リアジン, TPTH 剂の効果がすぐれていることが判明 し, 有機りん系のいもち病防除剤の出現により EDDP 剂の効果もすぐれていることが確かめられた ${ }^{3,4,7) . ~ ま ~}$ た防除時期については穗いもち対象の時期よりやや遅 い時期が望ましいことも指摘されている. 筆者らの試 験でも EDDP 剂の穗揃〜傾穂初期の薬剤散布が有効 で,この時期の 2 回散布により $\mathrm{TPTH}$ 剤にまさる効 果がみられた。なおこれらの楽剤防除試験においても 薬剤散布区は無散布区に比し葉身のごま葉枯病病斑数 は非常に少なくなって拉り, 穂枯れの発生と関俰があ るようにみられた。しかし穂ばらみ期の散布では葉身 の病斑数はかなり少なくなったが, 穂枯れの発生は穂 揃期以後の散布区より多くなっている点などから, 胞
子の飛散による穂への感染を直接防止しなければなら ない点が指摘できよう。

\section{引用文 献}

1) 藤井 溥 - 渡辺康正 - 堀野 修 (1968)：日植病 報, 34: 175 .

2) - - (1969): 日植病報, 35: 101 .

3）木谷清美 - 大畑貫一 (1967)：植物防疫，21：369 -372 .

4)- - - 久 久保千冬 (1969)：四国植防研究, $4: 1$

5）- - - - (1970)：四国農試報, 22: 27 $-117$.

6）越水幸男· 内藤秀樹 · 柳田騏策 (1970)：東北農 試研報, 39：111-135.

7) 森 喜作, 松田 明 (1963): 静岡農試研報, 8 : $43-62$.

8）鈴木穂積 - 山口富夫 (1972)：北陸農試報, 14 : $63-90$.

9）富永時任 (1970)：日植病報，36：369.

10）上原 等. 都崎芳久. 山本辰夫 (1967)：四国植 防砳究, 2: $1-8$.

11) 安 正純·柿崎 正·深津量栄・島田尚光(1962) ：指定試䩓（病害虫），1：1-229.

\section{Summary}

The present study was conducted to identify the causal fungi of ear blighting of rice plant, to make clear the relation between leaf blade infection and ear blighting, and to determine the proper timing of EDDP application for the control of ear blighting.

1. A large number of ear blighting samples were collected to determine the kind of causal fungi throughout Aichi Prefecture from 1967 to 1970. Main species detected were Helminthosporium sp., Cladosporium sp., Pyricularia sp., Cercospora sp., etc. Helminthosporium sp. and Cladosporium sp. were generally found on almost all the samples, while Pyricularia sp. and Cercospora sp. varied in their incidence with the locality or with the year. Cladosporium sp. has not been recognized to be pathogenic to rice plant. It is supposed, therefore, that Helminthosporium sp. is the most important causal fungus of ear blighting in Aichi Prefecture.

2. Distinct correlation was not found between the leaf blade infection with Helminthosporitm oryzae and the incidence of ear blighting under the field condition. In the concrete pot experiment, however, both leaf and ear infection with Helminthosporium oryzae was increased with the decrease of root vitality induced by the reductive condition of soil.

3. The ear blighting was effectively controlled by the application of EDDP spray from full heading stage to dough-ripe stage.

(昭47.12.1.受付) 